Research Notes

\title{
Man of the Year: The Saga of Private Reuben Johnson
}

\author{
Ian Kurtz \\ University of New Haven, New Haven, USA
}

Article history

Received: 14-06-2020

Revised: 28-08-2020

Accepted: 03-09-2020

Email: ikurtz@newhaven.edu

\begin{abstract}
This manuscript investigates a long forgotten American hero. Although Americans are no doubt familiar with prominent military names such as Audie Murphy, or Generals Eisenhower and MacArthur, amidst millions of unrecognized American veterans who contributed significantly to history. American Army Private First-Class Reuben L. Johnson came from humble beginnings and served his country heroically in the first world war. Many times, such stories are lost to history. Today, due to the tremendous power of the internet, we can finally learn the stories of obscure veterans such as Reuben.
\end{abstract}

Keywords: World War I, U.S. Army, Veterans, Unsung Heroes

\section{Introduction}

Though military veterans are no doubt a point of pride in many families, few actually understand the character of their loved one's service. The objective of this research is to trace an individual veteran's story. Reuben Johnson's military journey closely mirrors the approximately 2-year American involvement in World War I. It all began with the American declaration of war on the axis powers in April of 1917 and the subsequent draft of millions of American soldiers. This was followed by arduous training at stateside camps, the deployments overseas by ship, the participation in the great battles in the trenches of France, the armistice, the occupation and the well-earned journey home, Reuben's story overlays it all and his wartime experience truly represented the American experience. Reuben had a ringside seat to each of these historic events and when it was all over, was decorated with the Distinguished Service Cross, the US Army's highest award for valor (DoD, 2020). To understand its significance, consider this: Out of the nearly 5 million Americans, who served during World War I, just over 6000 received the medal (Fig. 1).

The information uncovered by this research, Reuben's time in service, his record overseas, his decoration for bravery and his effort to locate and retrieve, under dangerous conditions, the body of his commanding officer in order to be brought back for burial, has served as a source of astonishment, pride and ultimately comfort for his surviving family.

Internet sources such as online libraries, historical archives and genealogy research sites, provide modern power of discovery.

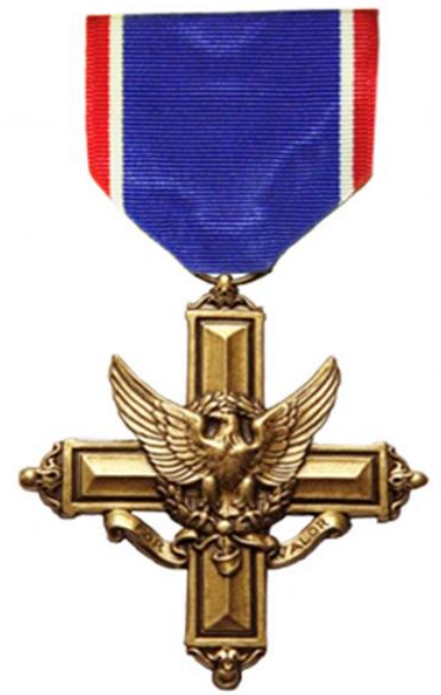

Fig. 1: The distinguished service cross

\section{Who was Reuben Johnson?}

Little is known about Reuben's early days. What is available is that he was born in Donovan, Illinois in 1896 and raised in nearby Paxton. Sometime around 1916, he and younger brother Frank relocated to South Dakota to seek farm work. This is where he was drafted and entered the US Army at Camp Dodge, Iowa in the early summer of 1917.

\section{Discussion}

This investigation began with an off-hand comment from a proud mother-in-law offering a bit of family history: 
“My grandfather's brother died in World War

I. He got gassed and his name was Reuben Johnson."

Initial internet searches yielded little to no information on a private named Reuben Johnson from Illinois. Many lists exist from the Great War, broken down by state, that show the names of the 100,000+ soldiers killed, though none displayed the name Reuben Johnson. Could his name have escaped the annals of history?

Traveling to Illinois with a portable scanner, private photos of the subject's distant family were scanned and placed on thumb drives. Eventually, a photo surfaced of Reuben in the uniform of the American Army, revealing an innocent-looking young man wearing the campaign hat featured in countless other photos of the American doughboys who fought "over there." (Fig. 2).

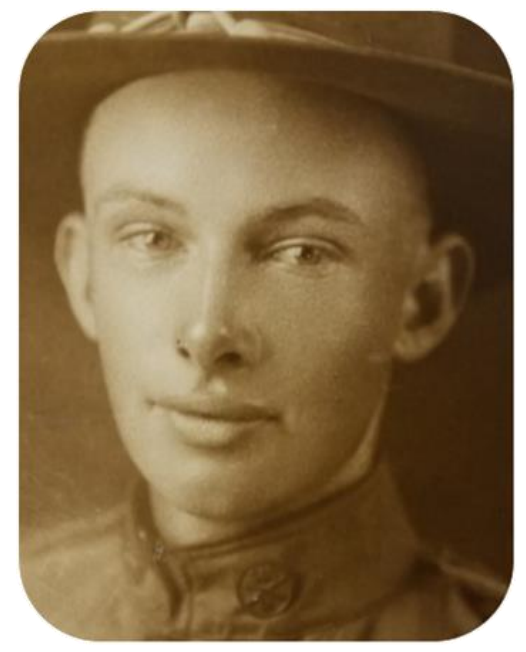

Fig. 2: Family-owned photograph of Reuben wearing a U.S. Army uniform

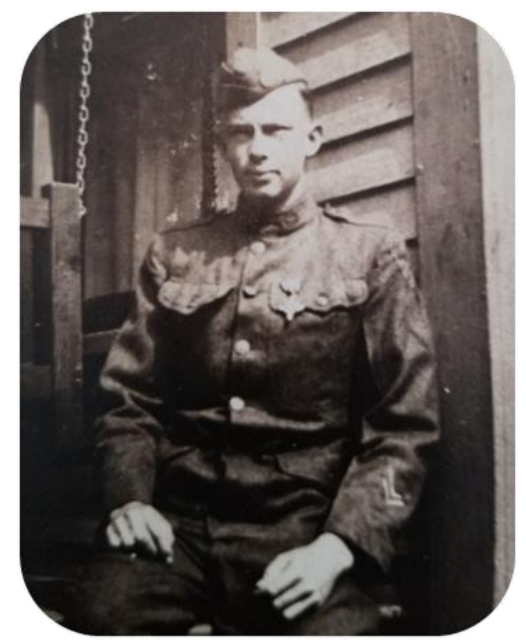

Fig. 3: Family photo of Private Johnson in full dress uniform
Notice in Fig. 2, the only visible insignia was his collar brass, featuring the crossed rifles of the infantry and the number "346." indicating the 346th infantry regiment, part of the 87 th Infantry Division (the "Golden Acorn" division) formed at Camp Pike, Arkansas.

Figure 3 reveals a second family photo in an old shoebox. The image shows Private Johnson in full dress uniform with an "overseas cap" (a version of the cloth folding cap still in use today) rather than the doughboystyle campaign hat. This time, the "innocent young man" looks old and worn - aged perhaps 10 years, though this picture could not have been later than 1920 since he is still in uniform. He is posing near the front of an old house with a porch swing next to him. Behind him, on the front door of the house, is an image of the red cross. Was this an old-time veteran's facility? Perhaps a medical rehab center? The young soldier's uniform features two "overseas chevrons" on the lower sleeve, indicating two 6-month periods in addition to something else adorning his uniform. The Distinguished Service Cross, the US Army's highest award for valor, second only to the Medal of Honor appears on his uniform.

The first obvious question from the gathered family members of Reuben was:

\section{"I thought he died in the war."}

Interviews with older family members reveal the main reason many assumed that he was dead: The fact that when referred to, most of the older folks simply said, "the gas got him." Perhaps he came home and then was sent over there a second time. This is unlikely. The American involvement in the war only lasted a couple of brief years, the chances of a doughboy being shipped overseas, fighting in battle, being decorated, returning home only to be sent overseas a second time, was virtually unheard of at that time. The practice of multiple tours took hold in the Vietnam era and the multiple deployments seen today.

Perhaps the Private simply borrowed the medal from someone simply for showing off for the photo? This is unlikely. A soldier would presumably give such a medal to another soldier for a photo opportunity very cautiously.

Perhaps while recuperating at a veteran's clinic, the Private was indeed awarded the medal and posed for a picture(?).

This confusion leads to main objective of the manuscript: To set the record straight through further historical research. How many other families are unaware of the service of family members?

\section{Methodology}

Where was a record of the medal? Was he wounded? US census information showed Reuben at home in Central Illinois in 1920. He had indeed returned from the war. A 2009 index compiled by C. Douglas Sterner documented over 13,000 Distinguished Service Cross (DSC) records from every major war that the Army has 
fought, to include the thousands from WWI (Stern, 2006). Private First-Class Reuben Johnson, from Donovan, Illinois, was drafted into the Army out of Ashton, South Dakota, was awarded the Distinguished Service Cross. The citation: (Military Times, 2020a):

The President of the United States of America, authorized by Act of Congress, July 9, 1918, takes pleasure in presenting the Distinguished Service Cross to Private First Class Reuben L. Johnson United States Army, for extraordinary heroism in action while serving with Company B, 47th Infantry Regiment, 4th Division, A.E.F., near the Bois-de-Brieulles, France, 28 September 1918. Although he had been painfully wounded in the back by a bursting shell, Private Johnson continued to perform his duties as a runner under heavy artillery and machine-gun fire, thereby enabling his company commander to maintain control of the company. He remained on duty until late in the night when he was ordered to the dressing station.

Internet sources trace soldiers from Camp Dodge who were sent to Camp Pike, Arkansas as replacements. Eventually, the Camp Pike soldiers are sent to Camp Dix, New Jersey where they board ships bound for England. Reuben is not among them. The manifest for the Delta, an overseas transporter, shows Reuben sailing to France as part of the "Camp Pike June Replacement Draft" and he arrives in late June of 1918 (Fold3, 2020). $\mathrm{He}$ is assigned to Company B of the $4^{\text {th }}$ Division's 47 th Infantry Regiment and spends the rest of war with them.

A comprehensive Regimental history printed sometime in 1919 when the war was no doubt still fresh in people's minds (Pollard, 1919) mentions Reuben several times. One interesting entry lists him as among those who have "officially known to have been awarded the DSC but whose citations are unavailable at this time" (p. 109). His name also appears on a long roster of names with the annotation of "W, TD" beside it (p. 145) meaning wounded and returned to duty. In Fig. 3, Reuben is not wearing a wound chevron on his uniform, though his DSC citation clearly verifies this.

The final interesting mention is a listing under "Additional Citations Awarded." The entry for Reuben reads, "With three other soldiers, went out under heavy machine gun fire to bring in from an exposed position in the face of the enemy, the body of Lieutenant Conrad Crawford (Fig. 4) and accomplished his mission" (p. 113). The citation goes on to say, "Note: This is probably the act for which Johnson was later awarded the DSC." Research had already determined that it was not; Crawford fell in battle the month before Reuben's DSC actions. No, this was simply another brave, selfless and no doubt difficult act performed by Private Johnson.

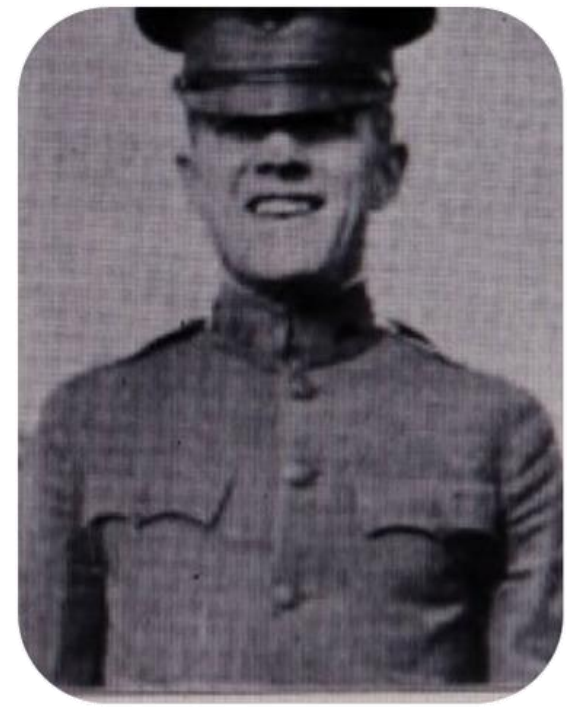

Fig. 4: Lieutenant Conrad Crawford (Hays, 2018)

The $47^{\text {th }}$ Regimental history further details the surrender of Germany, the cessation of hostilities and 360-kilometer foot march over three weeks of Reuben's unit from their final locations in northeast France to the Koblenz, Germany area (p. 72). Here, the $47^{\text {th }}$ served as occupational forces until the following July when word finally came for the over 5000 soldiers to return home.

\section{Epilogue}

Documents indicate that Reuben boarded the United States Transport Service Mobile, returned home to the US in 1919 and separated from the Army shortly thereafter (Fold3, 2020). Wounded like many others, he spent several years coping with the war's aftermath. He died in a Chicago veteran's hospital in 1928 at the age of 32. His circumstances in those final years (e.g., what types of ill effects he suffered) seem lost to history. His hometown of Paxton, Illinois is likely unaware of his wartime record.

\section{Conclusion}

This manuscript unearthed the additional story of Lieutenant Conrad Crawford. The Nyack, New York native was killed in battle in August of 1918. A Cornell University alumnus, Crawford had spent time in the New York National Guard and as a staff member of the New York Evening Sun before the war (Cornell University Alumni Notes, 1918). Crawford was killed while leading his company on a perilous mission to claim territory and liaison with a neighboring regiment. For his bravery in the face of difficult odds, he was posthumously awarded the Silver Star (Military Times, 2020b). Reuben and three comrades risked their lives to retrieve Conrad's body after he was hit in the chest by a machine gun's bullet 
(Find A Grave, 2010). Today, Lieutenant Crawford's grave lies in France. In 1919, along with other local natives killed in the war, the city of Nyack planted a tree in his honor (Nyack Park Conservancy, (n.d.)).

This research serves as a history lesson. Private Johnson's wartime experiences can be used as a case study for the typical infantry "doughboy." His unit fought valiantly in all the major campaigns for the American Army to include the second Battle of the Marnes, St. Miheil and the Argonnes Forest (Pollard, 1919). His journey from being drafted, stateside training, fighting in France, being decorated, wounded and returning home to spend his life recuperating, are a story of America's WWI victory itself.

\section{Acknowledgement}

This research was independently pursued by the author, but the genesis of the intellectual property was a graduate education in the U.S. Air Force nuclear enterprise's distance learning education program (Sands et al., 2017) in response to an increased need for critical thinking in the nuclear enterprise (Mihalik et al., 2017) in a period of global uncertainty (Sands, 2016; Sands and Mihalik, 2016; Sands et al., 2018a; 2018b; Nakatani and Sands, 2018; Bittick and Sands, 2019; Kuklinski et al., 2020). This manuscript constitutes the fifth publication resulting from the air force program following (Hall and Sands, 2020; Dmytryszyn et al., 2020; Kuklinski et al., 2020; Kurtz, 2020).

\section{Funding Information}

This research was independently pursued by the author, but the genesis of the intellectual property was a graduate education whose tuition was funded by the U.S. Air Force nuclear enterprise's distance learning education program. The APC was funded by the corresponding author.

\section{Ethics}

No ethical issues may arise after the publication of this manuscript.

\section{References}

Bittick, L., \& Sands, T. (2019). Political Rhetoric or Policy Shift: A Contextual Analysis of the Pivot to Asia. Journal of Social Sciences, 15(1), 92-125.

Cornell University Alumni Notes. (1918). Cornell Alumni News. https://ecommons.cornell.edu/handle/1813/26493

Dmytryszyn, M., Crook, M., \& Sands, T. (2020). Preparing for Satellite Laser Uplinks and Downlinks. Sci, 2(1), 16.
DoD. 2020. Description of Medals. Department of Defense. https://valor.defense.gov/Description-of-Awards/

Find A Grave (2010). 2LT Conrad Crawford. https://www.findagrave.com/memorial/56636648/co nrad-crawford

Fold3. (2020). Various historical records. Fold3.com subscription service.

Hall, D., \& Sands, T. (2020). Quantum Cryptography for Nuclear Command and Control. Computer and Information Science, 13(1), 1-72.

Hays, M. (2018). Nyack People \& Places: Labor Day 1918. Nyack News and Views. https://nyacknewsandviews.com/2018/08/nyackpeople-places-labor-day-1918/

Kuklinski, C. T., Mitchell, J., \& Sands, T. (2020). Bipolar strategic stability in a multipolar world. J. Pol. \& L., 13, 82.

Kurtz, I. (2020). University education in nuclear deterrence. Education. 10(2), 33-40.

Mihalik, R., Camacho, H., \& Sands, T. (2017). Continuum of learning: Combining education, training and experiences. Education, 8, 9-13.

Military Times. (2020a). The Hall of Valor Project. https:/valor.militarytimes.com/hero/12753

Military Times. (2020b). The Hall of Valor Project. https://valor.militarytimes.com/hero/80483

Nakatani, S., \& Sands, T. (2018). Eliminating the existential threat from North Korea. Sci. Technol, 8, 11-16.

Nyack Park Conservancy. (n. d.). History. http://nyackparks.org/history

Pollard, J. E. (1919). The Forty-seventh Infantry: A History, 1917-1918, 1919. Press of Seeman \& Peters.

Sands, T. (2016). Strategies for combating Islamic state. Social Sciences, 5(3), 39.

Sands, T., \& Mihalik, R. (2016). Outcomes of the 2010 and 2015 nonproliferation treaty review conferences. World J. Soc. Sci. Humanities, 2, 46-51.

Sands, T., Camacho, H., \& Mihalik, R. (2017). Education in nuclear deterrence and assurance. J. Def. Manag., 7(166), 2167-0374.

Sands, T., Camacho, H., \& Mihalik, R. (2018a). Nuclear Posture Review: Kahn Vs. Schelling... and Perry. J. Soc. Sci, 14, 145.

Sands, T., Mihalik, R., \& Camacho, H. (2018b). Theoretical context of the nuclear posture review. J. Soc. Sci, 14, 124-128.

Stern, C. (2006). Alphabetical Index of the Recipients of the Distinguished Service Cross. https://homeofheroes.com/wpcontent/uploads/2018/09/Distinguished-ServiceCross-Alph-Index-ALL-RECIPIENTS-July2008.pdf 